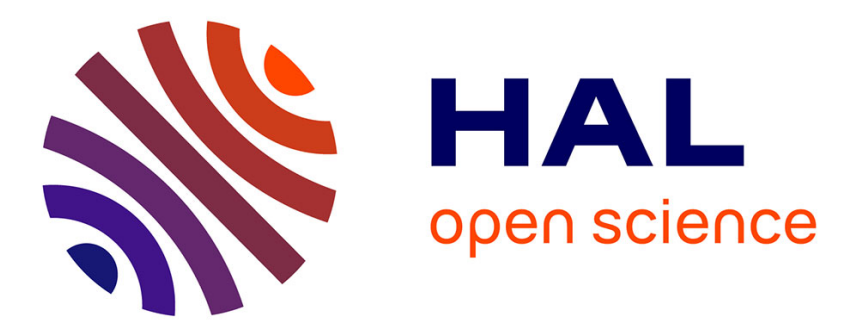

\title{
From Highway to Clubs: Buchanan and the Pricing of Public Goods
}

\author{
Alain Marciano
}

\section{To cite this version:}

Alain Marciano. From Highway to Clubs: Buchanan and the Pricing of Public Goods. James M. Buchanan. Remaking Economics: Eminent Post-War Economists, Springer International Publishing, pp.713-737, 2018, 10.1007/978-3-030-03080-3_32 . hal-02550420

\section{HAL Id: hal-02550420 \\ https://hal.science/hal-02550420}

Submitted on 8 Dec 2020

HAL is a multi-disciplinary open access archive for the deposit and dissemination of scientific research documents, whether they are published or not. The documents may come from teaching and research institutions in France or abroad, or from public or private research centers.
L'archive ouverte pluridisciplinaire HAL, est destinée au dépôt et à la diffusion de documents scientifiques de niveau recherche, publiés ou non, émanant des établissements d'enseignement et de recherche français ou étrangers, des laboratoires publics ou privés. 


\title{
32
}

\section{From Highway to Clubs: Buchanan and the Pricing of Public Goods}

\author{
Alain Marciano
}

\section{Introduction}

Not much has been written about the history of James Buchanan's "An Economic Theory of Clubs" (1965a), which is one of the most important of his articles. In another work (Boettke and Marciano 2017), we have shown why Buchanan's article should not be read as an answer or a complement of Charles Tiebout's "A Pure Theory of Local Public Expenditures" (1956). Our objective is now to shed as much light as possible on why Buchanan came to write about clubs. From this perspective, a point of reference is given by Richard Wagner: Buchanan started to discuss the provision and financing a local public goodmore precisely, a swimming pool—with students in the fall of 1963 (2017, pp. 181-182). Another date is important: August 8, 1964. It is not possible to know if Buchanan had already written his article on

\footnotetext{
A. Marciano $(\square)$

Faculté d'Économie, MRE and Université de Montpellier,

Montpellier, France

e-mail: alain.marciano@umontpellier.fr

(C) The Author(s) 2018

R. E. Wagner (ed.), James M. Buchanan, Remaking Economics: Eminent

Post-War Economists, https://doi.org/10.1007/978-3-030-03080-3_32
} 
clubs by that date but August 8, 1964 was when he started to write an article entitled "The Highway Network Considered as a Club".

The manuscript is made of different parts that may have been written later. Yet, it is certain that the pricing of highway services was the first area to which Buchanan tried to apply his work on clubs. We thus claim that the idea individuals could form clubs to finance public goods can be traced back to his first works on public finance, at the end of the 1940s, and relates to a very important question for Buchanan: the financing of highways and the pricing of their construction and of their use. Convinced very early in his career that users should pay (see Marciano 2018), Buchanan adopted first Knut Wicksell's proposal to use a marginal cost pricing rule. But, the many criticisms raised against this rule led him to abandon it and replace-or at least supplementit with clubs. The object of this paper is to retrace the steps that led Buchanan from marginal cost pricing to clubs.

\section{Voluntary Exchange Theory, Benham and Clubs}

To understand Buchanan's theory of clubs, one must go back to his dissertation_-"Fiscal Equity in a Federal State" (1948) — or to the preliminary version of "The Pure Theory of Government Finance" (1949a). In these works, Buchanan presented and defended the voluntary exchange theory of public finance that had been put forward by, among others, Luidi Einaudi, Maffeo Pantaleoni, Antonio de Viti de Marco, Erik Lindahl of Knut Wicksell. Buchanan's arguments were close to those he made in the published version of the article- "The Pure Theory of Government Finance: A Suggested Approach" (1949b). However, for both obvious - a dissertation is longer than an article-and less obvious - one of the reviewers suggested to shorten a paper that he found too long-reasons, Buchanan removed certain references when he revised his article. One of these references is not without interest for the purpose of this chapter.

Buchanan might have had difficulties to find references written by English speaking economists about voluntary exchange theory. The theory had not attracted much positive comments in England or in the USA 
(Johnson 2015). Henry Simons was one of those who had criticized it. Buchanan could not have ignored his criticisms of de Viti de Marco (Simons 1937) but, for some reason, did not cite him. He cited only Richard A. Musgrave and Frederic Benham, for having provided "a summary of the basic postulates of this theory" (1948, p. 50). The former had also criticized that theory (in particular, Musgrave 1939) while the latter had praised it. An Australian economist who taught at the London School of Economics and who later became a member of the Mont Pelerin Society, Benham had indeed found that Viti de Marco's Principii di Economia Finanziaria was "probably the best treatise on the theory of public finance ever written." (1934a, p. 364) ${ }^{1}$. He had also been the first to link de Viti de Marco and Wicksell_- "the second part of Wicksell's Finanztlheoretische Untersuchurngen forms a good supplement to the present volume" (1934a, p. 366; see Johnson 2015). In an interview, Buchanan later declared that he had then been convinced that "Benham was right and Simons was totally wrong" and that "he understood the impact of [de Viti de Marco's] book" (in Mosca 2016, p. 124).

Buchanan did not refer to this review in his dissertation, but to another of Benham's article, also published in 1934, and tellingly entitled "Notes on the Pure Theory of Public Finance" (1934b). In that article, Benham was more specifically interested in reviewing Einaudi's Contributo all ricerca della 'ottima imposta' (1929), but in the course of his discussion, he also made a connection with the work of de Viti de Marco, Pantaleoni and Wicksell. Also, and of particular importance for our purpose, Benham proposed his interpretation of Einaudi's theory of "neutrality" of taxation that he linked to the a theory of the state. ${ }^{2}$

Thus, Benham started by noting that, according to him, Einaudi had only one "end ... in mind" (1934b, p. 449) when he wrote about "optimal" taxation and it is "of having no ends" (1934b, p. 450). In other

\footnotetext{
${ }^{1}$ Simons had written that "[i]f his book is "the best treatise on the theory of public finance ever written," one hopes that it may be the last" (1937, p. 716)

${ }^{2} \mathrm{He}$ wrote: "[t]he sketch has been given to illustrate and explain this concept [neutrality]. And it is this concept which, in my view, Einaudi has in mind" (1934b, p. 455; emphasis added).
} 
words, he wants a "neutral" system of taxation and public expenditures, that is a system designed in order not interfere with taxpayers's preferences and choices, or that "translates into effect the voluntary judgments and preferences of the citizens, whatever they may be" (1934b, p. 450).

That said, Benham was left with a question about the institutions that could implement such a system. His answer was not empirical or historical. He proposed what he called "a logical explanation, from the economic angle, of why States continue to exist” (1934b, p. 451). He thus distinguished between two situations.

The first case is that of "a fairly small number of men in a certain area, without a State [who ...] have equal incomes and tastes" (1934b, p. 451). These individuals may want goods and services that must be provided collectively. That happens for two reasons. First, these services would not be produced privately at all - "a private entrepreneur would not provide them at all" (1934b, p. 451) - because the benefits they generate are "indivisible" (1934b, p. 452) and individuals cannot be excluded from their consumption or, when benefits are divisible, entrepreneurs are reluctant to provide these services because they "would have to depend on voluntary subscriptions, and some would give little or nothing in the hope that others would give more" (1934b, p. 452). Then, second reason, the collective provision of these services is more efficient than private provision. Hence, to benefit from these services, individuals have to form a state. Benham equated this process with the one that consists to "form clubs and similar associations" (1934b, p. 451; italics added). He thus viewed clubs as groups of individuals who decide "to spend part of their incomes upon the collective provision of certain services" (1934b, p. 451). In a club, no voting rules is necessary to determine how much would be produced and how much individuals would pay. Having identical tastes and incomes, individuals - the members-would receive the same benefits from the use of the good and then would pay the same tax- "all would contribute equally, for incomes and tastes would be equal" (1934b, p. 452). All would also contribute "voluntarily" (1934b, p. 452) under a crucial condition: "provided the others also agreed" (1934b, p. 452).

The second situation Benham envisaged was that of a group of individuals which is no longer homogenous, which does not imply that it is 
larger in size. He then abandoned the analogy with clubs to characterize these heterogenous groups made of individuals with different incomes and tastes, "including those arising from their different locations or occupations" (1934b, p. 453). These individuals also want goods and services that must be provided collectively because the benefits they generate are indivisible. Now, because of the differences between individuals, they will not desire the same amount of goods and services or pay the same price to use them. Their benefits are necessarily different. Then, decisions on "expenditures and contributions" (1934b, p. 453) must be made by voting. To guarantee neutral taxation, the only satisfactory solution was to choose the program that "would meet with unanimous agreement" (1934b, p. 453). To him, "[t] he postulate of unanimous agreement [was] implied in the concept of neutrality" (1934b, p. 453). Of course, some groups of individuals will want goods that others will not desire. They might nonetheless unanimously agree to produce the good, provided that some compensation be paid to those who did not desire it. The one case in which unanimous agreement would not work was "if some persons declare themselves unwilling to contribute anything towards collective services" (1934b, p. 453). Because of the indivisibility of the benefits, they could not be prevented to consume these services. However, de Viti de Marco, that Benham quoted, was convinced this type of behavior was "negligible in number or as ... pathological" (de Viti de Marco 1923, p. 114).

Thus, in both cases, individuals could be expected to voluntarily contribute to the provision of collective services-pay taxes_as long as they anticipate that others will also cooperate. The sum individuals willingly share with others determine the amount of collective goods or services that is going to be produced. And the role of the state is to collect taxes and provide the goods. Thus, this is a clearly individualist theory of the state-the latter implements what individuals want.

How much - if-Buchanan was influenced by Benham is hard to tell precisely. It nonetheless remains that his explanation of the existence of states was close to Buchanan's individualist theory of government (1948, 1949a, 1949b). It would thus not be surprising that Buchanan had been attracted by Benham's reading of Einaudi. In particular, Buchanan could have been interested by the example Benham chose to illustrate his analysis. 


\section{Roads: Benham, Wicksell and Buchanan}

Benham thus compared the provision of roads in either of the two environments he envisaged. In small groups, roads could well ben provided by private entrepreneurs_- "charging tolls" to users (1934b, p. 532) but it would be more efficient if these goods were provided by the state: "the inconvenience of frequent stoppages to pay tolls could be overcome if the State provided "free" roads out of taxation" (1934b, p. 452). It is one of the case, in which "the State can provide [services which could be sold by entrepreneurs] to greater advantage" (1934b, p. 532). Similarly, the state should also provide roads in heterogenous groups, but the reason put forward was slightly different. Following what Wicksell had written in his Finanztheoretische Untersuchungen - the book that was so important for Buchanan and that had not be translated in English yet-Benham included roads in the category of goods that generate indivisible benefits "which would not have paid a private entrepreneur" (1934b, p. 454). The only means to finance them is by charging taxes and delegate the task to provide them to the State. The reason was "the State can charge different prices to different people while the entrepreneur cannot discriminate so completely, if indeed he can discriminate at all” (1934b, p. 454). Benham distinguished between the prices charged by private firms - that are identical for all consumers - from taxes- that can vary from one taxpayer to the other.

Roads, in Benham's analysis, may have reminded Buchanan that, in the early 1930s, he went to college in Murfreesboro-at the Middle Tennessee State Teachers College-“on a day-student basis" (2007, p. 35). Murfreesboro was only a few miles away from the village where Buchanan lived, but, in those years, even traveling only a short distance could have been quite difficult. The state of roads, that was bad in the South in general, was worse in Tennessee. The improvements that had taken place in the second half of the 1920s and in the 1930s remained insufficient. Farmers were particularly affected. They needed better roads to improve the delivery of their products to markets, to "break the railroad's monopoly on the shipment of farm products" (Pierce 2010) and also "end [their] social isolation" (Weingroff 2017, p. 7).

Yet, farmers had not seemed ready to finance roads. More precisely, until the beginning of the twentieth century, roads and highways were 
financed and maintained locally under the form of a "labor tax", that consisted in paying "their local taxes by spending a day or so each year actually working $\ldots$ on the improvement of their communities' public roads" (Preston 1991, p. 20). The system did not work very well: "[m] ost citizens never spent a day doing road work, preferring either to pay the small annual fine or to enlist the assistance of a local politician who had the power to grant a permanent exemption from the requirement" (Preston 1991, p. 22). To solve the problem, the state overtook the provision of roads and raised taxes to finance them. A property tax was then introduced but that was insufficient too because the there were more and more roads to be built and maintained. To solve the problem and raise enough money to finance and maintain roads and highways, states issued bonds - that counties were obliged to buy. The justification was indeed that "roads had come to be regarded as a general benefit, for which the general public should pay the larger part, if not all, of the cost" (Martin 1923, p. 73). In other words, that was the situation that Benham (and Wicksell) had described.

No difference was made however, in public policies, between state and local roads; all roads were treated as if they were the same type of public good, consumed by the same public. That had not appeared in Benham's typology either. But, also, no difference was made between users and non users. The first aspect was apparently not perceived but the second was. The increase in the size of the road network and in expenditures, and the insufficient amount of money generated by bonds, gave birth to the idea that motorists should pay for the surfaced or paved roads they were almost the only ones to use- "the building and maintenance of roads is in very large part a special service to the users of motor cars, and that, therefore, the motorists should be called on to pay most of the cost" (Martin 1923, p. 73). License fees were added to complement the resources provided by bonds, but they had two flaws: they were costly to implement and did not provide enough resources either. That was why was eventually introduced an earmarked tax for highways, the gasoline tax, first in Oregon in 1919 and in 1923 in Tennessee. Then, the road system really started to improve. That is, roads started to improve when a specific, earmarked, tax was adopted to finance them.

The centralized collection of the gasoline tax raised a specific problem: how to share the taxes collected by the state with the counties that 
needed them to built and maintain roads and highways? Answering the question was precisely the purpose of the master essay Buchanan wrote in 1941, when he was at the University of Tennessee, Knoxville. In his essay, Buchanan made a few points that deserve to be noted. First, Buchanan claimed that roads should be managed by the "state". At least, he acknowledged that the cooperative solution-based on a "labor tax", in which individuals were supposed to work "a few days per year spent in clearing of rights-of-way, grading, etc.” (1941, p. 13)—had not worked well-the system "was very inefficient and unsatisfactory" (1941, p. 13). And he noted that it had also been the case it had been private companies had taken over the provision of roads. This implied the need for a certain centralization in the collection of resources. Second, he accepted that roads should be financed via a gasoline taxrather than by another of the other mechanisms that had previously been used, property tax or "labor tax". The reason was that roads should be financed by those who use them. Indeed, and this is a third point, users receive benefits from using roads or, more globally, for consuming collective services.

In other words, Buchanan had found in the works of published economists answers to the some of the questions had discussed in 1941. These economists suggested that farmers may not have "paid" labor taxes because they had observed that others were not paying-the necessary condition for having a club was not satisfied. Also, it legitimized one of the intuitions he had had in his master essay-users should pay for roads but also that the state should collect taxes and built and maintain roads. It also allowed him to answer the question of how much should users pay. Benham had linked the tax to the individual benefits. Was it possible to be more precise and go further than Benham? Yes.

\section{The Pricing of Highway Services}

Indeed, reading Wicksell and using his insights, Buchanan could set up the basis that would allow him to explain how to price highway services. This is what he did in his first article specifically devoted to Wicksell (1951). He explained that public enterprises should "charg[e] fees equal 
to the marginal costs of providing the service and making up the deficit by tax revenues" (1951, p. 174). In the specific case of public enterprises that are already in operation, taxation would be used to cover fixed costs (1951, p. 176). However, these taxes should not be levied on all the taxpayers_-including non users_-way as said Harold Hotelling (1938) or Abba Lerner (1944). The type of pricing Buchanan envisaged was grounded in a benefit theory of taxation: taxes should be paid by "the individuals who benefit from the proposed enterprise" (1951, p. 176); "[t]he losses must be made up from "contributions" paid by those benefited" (1951, p. 178) or Wicksell's solution "does not require collection of taxes from any one other than the specific beneficiaries" (1951, p. 178). Actually, as he himself stressed it, his approach was "similar to the multi-part pricing systems proposed by Coase and others" (1951, p. 178; see Coase 1946). With a difference: "voluntarism" (Buchanan 1951, p. 178). He did not doubt that individuals, who receive benefits from using certain gods, would pay the taxes they were asked to pay. And, another difference that Buchanan did not mention yet, discrimination among taxpayers.

That Buchanan had a theoretical frame about the pricing of road or highway services in the early 1950s was particularly timely. Indeed, in the immediate post-WWII U.S.A., roads still represented "major social problem" (Buchanan 1952, p. 97). A problem that was nonetheless slightly different than in Tennessee in the 1930s. It was no longer a matter of how to share a sum between different levels of government but rather how to find these funds. And, another difference, one was talking of state or national roads only and no longer of local roads. As Buchanan noted, it was now "an area of emerging national importance" (1958, p. xvii). The problem had two dimensions: on the one hand, the size of the network was insufficient to face, on the other hand, the increasing traffic flow. To deal with this twofold problem, the government was trying to build more infrastructures and expand the size of the networkwithout realizing that there was an optimal traffic flow for each given network. Buchanan then suggested to rather focus on the regulation of the traffic flow, that is on the use-or consumption or demand-of the network. And economists knew how to do that: by using of a price mechanism. They also knew how to determine the price that would lead to an 
optimal traffic flow, namely by setting the price at the level of the marginal cost. This is precisely what he explained in the first article in which he applied Wicksell's theory, "The Pricing of Highway Services” (1952).

But, and Buchanan certainly did not ignore this aspect, roads are what would later be known as impure public goods; the quality of the services they provide depends on the number of users; congestion reduces this quality and creates a "'spillover' cost represented in poorer service provided all users" (Buchanan 1952, p. 100). This did not represent an obstacle to the use of a price mechanism but was rather a condition that could not be neglected. The price to charge still had to be set at the level of the marginal cost but spillover costs had to be included in the calculus. Thus, the "correct price" for highway services correspond "to the marginal social cost incurred in providing a unit of that type of service" (1952, p. 100). And, of course, as said in the 1951 article, this was a realistic solution since individuals were be ready to pay a price even if it included the external costs imposed on others because of the benefits they receive from using roads and highways.

Buchanan repeated the same claim in different notes he wrote around the mid-1950s in preparation for his article on "The Road Case Re-Examined" (1956). In a first note- "Resource Allocation and the Highway System"-Buchanan explained his purpose: to determine "the proper amount of the nation's economic resources which should be devoted both to the utilization and the construction of the highway system" (1954a, p. 1). But he was perfectly aware of the "external diseconomies in the consumption or utilization of highway services" (1954a, p. 2). In another note, written during the fall of 1954 and entitled "Consumption Interdependence and the Interpretation of Social Cost", Buchanan insisted again that "[i]n the presence of either external economies or diseconomies of consumption, the competitive economy should not appear to allocate resources properly." (1954b, p. 2).

Yet, he still believed that one should use prices. He insisted that "it is necessary that the prices of highway services be set equal to the marginal social costs of providing such services" (1954a, p. 6; emphasis added); or that the price "includes the incremental costs (or reduced enjoyments) imposed upon other road users!" (1954a, p. 6). Or, in 1955, " $[t]$ he answer to the whole highway problem lies in "pricing" the highway correctly. The existence of congestion on our streets and highways 
is solely due to the fact that we do not charge high enough "prices" for their use. This is one of the main functions of price in our free enterprise economy" (1955b, pp. 14-15).

Eventually, in "The Road Case Re-examined”, he wrote that he only "meaningful criterion for operational efficiency" (Buchanan, 1956, p. 315) was such that "the government... own the roads and price the road services at the level of marginal social cost" (1956, p. 315). That result indeed combined what Benham had written about Wicksellroads should be built and maintained by the state, even if a club of users existed - and what he had put forward about the pricing of road services in terms of marginal social cost.

\section{Some Criticisms of Benefits and Marginal Cost Pricing}

Pricing public goods as it could be done with private goods was not easily admitted. One of the strongest criticisms was Paul Samuelson's. In his famous "A Pure Theory of Public Expenditure" (1954), he reached definitive negative conclusions about the possibility to use a decentralized mechanism — including voting — to lead individuals to pay a price corresponding to their marginal rate of substitution between a private and a public good. The only condition that one could impose to reach an optimal allocation of resources bore, as it is well known, on the sum of the individual marginal rates of substitutions. Prices, or taxes, could not be individualized — at least not according to individual benefits. Pricing public goods by using a benefit theory of taxation as it was done with private goods was impossible (Samuelson 1954, p. 389). ${ }^{3}$ This implied,

\footnotetext{
${ }^{3}$ Samuelson "emphasize[d] this: taxing according to a benefit theory of taxation can not at all solve the computational problem in the decentralized manner possible for the first category of "private" goods to which the ordinary market pricing applies and which do not have the "external effects" basic to the very notion of collective consumption goods" (1954, p. 389). As noted by Maxime Desmarrais-Tremblay, another argument was that marginal cost pricing could not be used for public goods or in the case of decreasing costs because it would to set zero prices (2016, p. 133).
} 
by extension, that marginal social cost pricing could not be used for pure public goods.

Buchanan almost immediately wrote a comment that he first sent to Julius Margolis in January 1955 and then to Samuelson in February. He defended the idea that a benefit theory of taxation could not be abandoned. The reason lied precisely in the fact that the prices for public goods may differ from one individual to the other - they "depend upon the manner in which the real costs of the collective goods are allocated among individuals, that is, on the structure of the tax system" (1955a, p. 3). This means that any change in the quantity of supplied public good will be borne differently by all the individuals; some will pay more than others. Hence, to guarantee the Pareto optimality of the change in the supply of a public good, one had to be sure that the gains of the winners will not be made at the expense of the other individuals. Hence, one had to add a condition to guarantee how the marginal costs would be distributed among individuals. He then suggested that the "tax bill" or the "tax burden" should be allocated according to a benefit principle, that is by guaranteeing that "each individual must equate the marginal rate of substitution in consumption between any one collective and private good with the marginal rate of substitution between these two goods for him" (Buchanan 1955a, p. 3; emphasis in original). Hence, to push Buchanan's analysis one small step further, this condition about the sharing of the marginal costs of the provision of an additional unit of public good could restore the marginal social cost pricing rule.

Samuelson was not, however, the only one who criticized the pricing of public goods. For instance, Oscar Brownlee and Walter Heller agreed that "highway services should be priced in much the same manner as other services would be priced in a competitive market" (1956, p. 237), citing Buchanan as one reference on that. They nonetheless insisted on the practical difficulty to collect information about how motorists use highways and which prices they should pay. Hence, to them, "deciding precisely what prices should be charged for each of the various kinds of services would prove to be a difficult [problem] to solve" (1956, p. 237).

Shortly after-his paper was published in August 1957Margolis also reached a pessimistic conclusion about the possibility 
to price a public service. He studied the case of an irrigation project, noting a decision about building a dam and distributing water had two dimensions. First, one had to determine the optimal size of the dam and the network. Margolis demonstrated why this optimal size should be such that "the value of the marginal product of water is equal to the marginal cost of providing the water" (1957, p. 451). Second, one had to price the use of the system. Among the different possible systems that could be used, Margolis concluded that "[a] two-part, or a discriminatory, pricing system, or a combination of both, is necessary to allocate water efficiently" (1957, p. 462). Indeed, "it achieves the optimal output, since the price of the marginal unit purchased by each consumer equals its marginal cost" (1957, p. 452) —in other words, he agreed with Buchanan. In addition, did he add, this method "permit[s] projects to be financially independent and thereby autonomous" (1957, p. 462). Then, he nonetheless also stressed "that efficient pricing practices are unlikely" (1957, p. 462). Inefficiencies in government production should be accepted. That was unavoidable. He thus also agreed with Samuelson.

Also in 1957, was published "The Theory of Public Utility Price-An Empty Box", written by Jack Wiseman who concluded that "no general pricing rule or rules can be held unambiguously to bring about an 'optimum' use of resources by public utilities, even in theory" (1957, p. 56). Wiseman criticized Hotelling's marginal cost pricing and multi-part pricing "both in its simple form and as modified by a 'club' principle" (1957, p. 57). According to this principle, rather than paying "a price per unit equal to marginal cost" (1957, p. 64), each consumer pays "a fixed charge ... that part of the common cost that he has stated his willingness to bear" (1957, p. 64). But, to Wiseman, clubs do not really involve voluntarism —individuals' "agreement [is] 'voluntary' ... in the special sense that a malefactor voluntarily goes away to prison after a judge has sentenced him; he chooses the best alternative still available" (1957, p. 66). The only type of clubs that Wiseman viewed acceptable in terms of voluntarism was "the direct production club ... created and administered by the consumers themselves" (1957, p. 66; emphasis in original). But it "seem[ed] unlikely to be of widespread importance" (Wiseman 1957, p. 67). Thus, the club version was no more satisfactory than the simple version of multi-part pricing. 
Buchanan did not immediately react to Margolis's or Wiseman's articles. There is no direct evidence that he read them, but one may assume that he did. At least, he was sufficiently interested in the question to invite Brownlee to present a paper at the conference on "Public Finances: Needs, Sources, and Utilization" he organized in 1959-Tiebout and Musgrave and also Margolis attended the conference. In his paper, "User Prices vs Taxes" (1961), Brownlee developed the same kind of reasoning as in his 1956 article on highways. He explained that he "favor[ed] using price as a rationing device wherever a reasonable opportunity exists" (421), and compared the pricing of highway services to the pricing of education and being more favorable to pricing of education services than highways'. But, he also concluded that "[a]llocating government services by pricing them has limited applicability" (432). A skepticism that Buchanan eventually shared, since he accepted the view that marginal cost pricing or multi-part pricing should be abandoned. And then chose club financing instead. Before he came to that, however, he made other steps that also contribute to his analysis of clubs.

\section{Problems with Majority Voting}

As said above, part the criticisms against pricing public goods bore on the difficulty to determine prices. "The solution "exists", had written Samuelson, "the problem is how to "find" it" (1954, p. 389). Buchanan could not ignore it. Meeting Gordon Tullock-in 1958led him to study and write about that problem. From this perspective, The Calculus of Consent (Buchanan and Tullock 1962) provides an answer to Samuelson in that it shows that majority voting rules are imperfect but also decisions about the provision and pricing public goods and the internalization of externalities could efficiently be made via voluntary private arrangements, rather than through government intervention: if property rights are correctly defined, "voluntary cooperative arrangements among individuals emerge to insure the elimination of all relevant external effects" (Buchanan and Tullock 1962, p. 44). To them, there was no doubt that individuals were willing to 
organize-spontaneously and voluntarily-collective actions between them to deal with externalities. However, they departed from the position that consists in claiming that individuals would always voluntarily cooperate with others to which Buchanan had stuck since the 1940s. From this perspective, two chapters-ten and eleven-based on articles respectively written by Tullock and Buchanan deserve particular attention.

Chapter 10 of The Calculus of Consent was based on Tullock's "Problems of Majority Voting" (1959) and bore on a question that could not but interest Buchanan: the repair and maintenance of roads in a community of farmers. The issue was political in that the decisions about which roads would be repaired and how much each farmer would pay were made by voting - using a majority rule. Farmers were asked to vote for proposals of repair and maintenance of their own and also of others' roads. Tullock took as a democratic benchmark-the Kantian solution - the situation in which individuals "vote to repair a given road in the same way as he would vote for repairs his own road" (Tullock 1959, p. 573). Kantian farmers were thus those who follow a sort of Kantian ethical rule. Would individuals behave as Kantians?

No, explained Tullock: "any individual farmer" has interest in behaving as a maximizer, if he expects others to behave as Kantians. That is, he has an interest in voting only in favor of proposals to repair their road and against the proposals aimed at repairing the roads used by other famers. Indeed, "his taxes would be reduced, or his road kept in better-than-average repair" (1959, p. 574). If other farmers imitate him, this would increase the standard of repair on their roads, decrease the standard of repair on others' roads while reducing their share of the costs and increasing the costs incurred by other taxpayers (1959, p. 574).

On the whole, the general level of repair of the roads would be lower in a community in which individuals behave as maximizers rather than as Kantians. And that would be at the advantage of maximizers and at the disadvantage of Kantians since the latter support the cost of repair of the roads of the maximizers who, by contrast, only pay for the repair of their own roads or those of the members of their coalition. Kantians are "exploited by the maximizers" (1959, p. 574). Then, since "virtue 
... conspicuously is not paying" (1959, p. 575), they become "tired" (1959, p. 574) of "never hav[ing] his own road repaired [while] pay[ing] heavy taxes for the support of repair jobs on other roads" (1959, p. 576) and eventually "switch to a maximizing pattern of behavior" (1959, p. 574). To be more precise, there exists a threshold in the number of maximizers within the group of farmers under which Kantians accept to be exploited. Kantians tolerate a certain number of maximizers in the community before departing from the moral rule. When the proportion of maximizers becomes too important, Kantians too change their behavior and become maximizers.

Thus, Tullock provided another explanation to the failure of the labor tax Buchanan had heard about when he was young, and mentioned in his master essay: some of the farmers were maximizers and refused to cooperate, even if other were ready to cooperate. That implied, as a corollary, that individuals could free ride, even in small groups or, in other words, that homogeneity in tastes and incomes did not guarantee that individuals would cooperate. Benham's clubs seem to lose consistency. In addition, Tullock also demonstrated that "the system of majority voting is not by any means an optimal method of allocating resource" (1959, p. 579). Under majority voting, some individuals could impose taxes that would exceed the benefits they receive from consuming collective goods.

Buchanan developed the same ideas in a few papers that he wrote at the same time. Thus, in "Simple Majority Voting, Game Theory and Resource Use" (1961) — the paper was submitted for the first time in August 1960-Buchanan extended and deepened Tullock's analysis. ${ }^{4}$ Starting with the same problem-farmers and road repair-he discussed how collective decisions could be made in a simple majority voting process. Then, like Tullock and even though he did not refer to Kant, Buchanan distinguished behaving ethically or morally-that is being "interest[ed] in the welfare of his fellow citizen" (1961, p. 340) from utility maximization. And his conclusion was similar to Tullock's:

\footnotetext{
${ }^{4}$ The paper appears under the title "Simple Majority Voting and The Theory of Games" in The Calculus of Consent (1962, Chapter 11, pp. 143-164).
} 
as the size of the group increases, any tacit adherence to moral or ethical principles that might inhibit individual utility-maximizing behaviour becomes more difficult to secure. ... the individual's interest in the welfare of his fellow citizen falls off sharply as the group is enlarged. (1961, p. 340$)^{5}$

Hence, one should distinguish small groups - in which individuals cooperate-from large ones_-individuals no longer cooperate because the ethical rule of behavior loses strength. This was the first occurrence of that idea about "numbers" that Buchanan will insist on over the next few years (see Marciano 2016). It started with "Ethical Rules, Expected Values, and Large Numbers" (1965b), an article that Buchanan wrote as an extension of his papers on clubs. On March 15, 1965, he wrote Roland McKean about "a piece that I plan to send off to an ethics journal... it spells out the importance of small numbers." 6

But in the early 1960s, Buchanan rather insisted on another problem: coalitions that could impose costs on minorities. He made that point in a discussion of the case of the provision of purely collective goods that "provide equal benefits to all members of the group" but "are financed by taxes that may be levied in a discriminatory fashion among the separate individuals and groups in the population" (1961, p. 344). He then demonstrated that " $[a]$ ny project yielding general benefits ... will tend to be approved by the dominating majority if they are successful in imposing the full tax cost onto the shoulders of the minority" (1961, p. 344; emphasis added). Which not only meant that there was not limit to social wastage but also that these wasteful public projects benefit to the members of the majority while being paid by the members of the minority - they pay "differentially higher taxes" (1961, p. 345). It was a situation that Buchanan had identified as preventing

\footnotetext{
5That was also a point one also finds in "A Note on Public Goods Supply" co-authored with Milton Kafoglis: even if private arrangements could be said to be efficient, there were circumstances in which they would be too costly to organize, in particular, did they write, "when the interactions extend over a large number of persons" (1963, p. 412).

${ }^{6}$ Buchanan to Roland McKean, March 15, 1965, BP.
} 
the use of the marginal cost principle à la Wicksell (1951, p. 176). Indeed, the price paid by the members of the minority does not correspond to their marginal benefit nor to the marginal social cost their activity generates.

The problem might be corrected — and social wastage avoided. First, if the principle of discriminatory taxes to finance collective projects was abandoned (1961, p. 345). In that case, individuals could be expected to vote in comparing or "balanc[ing] off some pro rata share of total marginal benefits against an appropriate pro rata share of total marginal costs" (1961, p. 345). Thus, the benefit principle would be rescued and one could then envisage to use again the marginal cost pricing rule. But, added Buchanan, unless constitutionally forced to do so, no majority would ever propose a project that does not generate "differential benefits, differential taxation, or both" (1961, p. 345).

Another solution was envisaged in a paper that Buchanan also wrote in 1960 - but that was published in 1962 - "Politics, Policy, and the Pigovian Margins" (1962). He was then trying to understand under which conditions majority voting would remove what he called the "Pigovian divergence", that is the difference between the marginal private and social costs. To him, this was possible only when each individual "is required [to vote] by includ[ing] in his calculus a share of the total marginal cost ... that is proportional to his individualised share of the total marginal benefits" (1962, p. 26). Here, taxes could vary from one individual to the other but the result would be the same: "the individual voter must pay for the marginal unit of the collective good or service in proportion to the marginal benefit enjoyed" (1962, p. 26). Yet, such a cost-sharing mechanism was "politically unimaginable" (1962, p. 27) and "conceptually impossible" (ibid.). Hence, it was "of little practical value" (1962, p. 28). No realistic mechanism existed that could prevent the members of the majority to oblige the members of the minority to pay more than their share of the total marginal costs. A conclusion that seemed to imply that the marginal social cost pricing rule to which Buchanan had stuck since 1951 was not going to be used if decisions were made at the majority. Did this mean that he was no longer convinced by the marginal cost pricing rule? And would this not imply that Samuelson was right (and that pricing of public goods should also be abandoned)? 


\section{From Marginal Social Cost Pricing to Club Pricing}

Buchanan made the step from marginal cost pricing to clubs between 1962 and 1964. As he wrote George S. Tolley, when discussing of the possibility to present papers in February 1965 at North Carolina State - the branch of the University of North Carolina in Raleigh-,

I could talk on "An Economic Theory of Clubs", which will be published soon in Economica. Or alternatively, I could talk on the topic "Some Fallacies in the Interpretation of Highway Costs", a paper that I have not written, but which I hope to get started on during this term. ${ }^{7}$

A few days later, Buchanan gave additional details about that paper on highway costs. He wrote that he had, "influenced by Davis-Whiston on externalities, now come to the view that all the stuff on trying to 'price' highways by measuring marginal costs of congestion, a position that [he] firmly supported in past, is conceptually wrong because it is impossible." 8

Buchanan was probably referring to "Externalities, Welfare, and the Theory of Games" (1962), in which Otto Davis and Andrew Whinston had demonstrated that the marginal cost pricing rule could be used only when (technological) externalities are separable (1962, p. 247). ${ }^{9}$ Now, the externalities generated by highway users were obviously nonseparable since indirect marginal social costs "clearly increase in some direct relation to traffic density" (Buchanan 1952, p. 100). Indeed, he had to abandon his objective to price highway services at their marginal social cost. Did it imply that one should no longer price highway services, as Samuelson and others had suggested? No. Buchanan then noted that "the use of price to restrict usage to some "optimal" level of traffic remains relevant [but], we should, I now think, come at price

\footnotetext{
${ }^{7}$ Buchanan to Tolley, October 7, 1964, BP.

${ }^{8}$ Buchanan to Tolley, October 19, 1964, BP.

${ }^{9}$ An externality is separable if the consumption or output of $i$ does not affect the marginal utility or cost of $j$. Otherwise, it is non-separable.
} 
differently, and not via the cost side at all." 10 How should it be done? Precisely by using the ideas he had on clubs, did he write. This is where we must refer to "The Highway Network Considered as a Club". ${ }^{11}$

In this draft, Buchanan first discussed the approach that he had defended for more than a decade, that consists in pricing highway services at the marginal social cost. That rule could not be used in the case of highways as it could - one would note the example chosenfor water-supply facilities. The use of such facilities could be rationed by charging a specific price or tariff. This is what Margolis had demonstrated in 1957, concluding also that this would generate a revenue sufficient to cover also the investment costs. That was not the case with highways that are "fixed facilities with private adjustments" (1964; emphasis in original) and for which "the government provides, or supplies not a final quantity of services, but, instead a fixed quantity, which, depending on how it is utilized may produce varying amounts of final output." Then, a two-part tariff could lead to an optimal use but, even if congestion costs were computed and included in the tariff, would not guarantee that the revenue thus generated would be sufficient to cover the investment in the facility. To deal with the problem, Buchanan used the concept of "club". Put differently, he switched from two-part pricing in its simple form to two-part pricing in its club form.

As he would do in his 1965 article, Buchanan defined clubs as cost-sharing arrangements-"a club as an organization of persons designed solely for the objective of utilizing a single communal community. Each "member" contributes to the common cost of maintaining the facility and each member also envisages the benefits of its availability" (1964). Beyond the definition in itself-which is interesting because it establishes a connection with Wiseman and Benham-it is important to note the twofold objective Buchanan assigned to clubs: to "determin[e] the most "efficient" size of the commonly-used facility, along with the

\footnotetext{
${ }^{10}$ Buchanan to Tolley, October 19, 1964, BP, George Mason University, Library, Special Collections.

${ }^{11}$ We refer to this manuscript as one unique document dated from 1964.
} 
most "efficient" size membership of the club" (1964). Hence, the optimal network was the point for which "the optimal size of facility for a given traffic flow be equal to the facility that generates the same traffic flow as optimal" (1964).

Obviously, in the same community, individuals could not be allowed to use different highway networks. The size of the facility had to be chosen in the first place. Without giving much details, Buchanan wrote that if this collective choice respected individual preferences- he noted that it should be the case in a democratic economy-, then the chosen network would be the one "collectively judged to be efficient of optimal" (1964). The optimal size of the facility was reached when "the marginal gains from an increased size just equal the marginal costs" (1964). Then, once this optimal network had been chosen, one could choose the optimal traffic flow, the optimal number of users- that is the optimal size of the club. It would be "attained when the marginal benefits secured from adding another unit of traffic is just equal to the marginal costs" (1964). The goal was thus to charge an individual fee that would allow to reach this point.

But then, there remained the criticism Wiseman had raised against clubs and the impossibility to respect voluntarism and to impute costs to individuals without coercion. It seems that Buchanan had only repeated exactly what Wiseman had already rejected. Yet, Buchanan could not accept a criticism that challenged his Wicksellian approach of the relationships between individuals and the state. This is precisely why, according to us, he explained that, with clubs, there was no need to determine the spillover costs and to impute them to individuals. By contrast with marginal social cost pricing, spillover costs were no longer taken into account in the price charged to users but rather through the decrease in benefits due to the increase in the number of users:

[t] he club approach, by contrast, involves no attempt to impose a charge on users that reflects spillover congestion costs. Users pay a share in the common costs of providing the facility; costs that are initially borne by the supply providing agency. The costs of congestion enter the analysis through their effects on the estimated benefits to be received by final consumers. (1964) 
Thus, to a certain extent, they were no longer included as costs but as foregone benefits. In other words, clubs were pricing mechanisms that could replace two-part pricing. He could safely "abandon" marginal social cost pricing: he had found another way of pricing the use of highways.

\section{Conclusion}

Early in his career, Buchanan acquired the conviction that public goods should be priced-like private goods - at their marginal cost. Taxes could complementarily be used to cover losses a public enterprise would incur because of this rule. In addition, those prices should be set at the marginal social cost to include the spillover costs that using public goods generate. That method of pricing public goods was known as a form of two-part pricing. In many of his writings about highways and roads, Buchanan repeated that highway services should be priced at their marginal social cost. But, at some point, because of the many criticisms that had been raised against this rule, he switched to "club" pricing. The move seems to have been inspired by Wiseman: the note he wrote about highways as clubs answered the latter's criticism against clubs. Clubs were thus, this is the claim we defend in this chapter, a means to replace marginal social cost pricing_or multi-part tariffs-that had become increasingly difficult to defend without abandoning the objective of pricing public goods and services.

\section{References}

BP-Buchanan Papers: James M. Buchanan's Archives, Special Collections Research Center, George Mason University Libraries, George Mason University.

Benham, F. C. (1934a). Review Principii di Economia Finanziaria by A. De Viti de Marco; Grundlehren der Finanzwirtschaft by A. De Viti de Marco. Economica, 1(3), 364-367.

Benham, F. C. (1934b). Notes on the Pure Theory of Public Finance. Economica, 1(4), 436-458. 
Boettke, P. J., \& Marciano, A. (2017). The Distance Between Buchanan's "An Economic Theory of Clubs" and Tiebout's "A Pure Theory of Local Public Expenditures". New Insights Based on an Unpublished Manuscript. European Journal of the History of Economic Thought, 24(2), 205-237.

Buchanan, J. M. (1941). Gasoline Tax Sharing Among Local Units of Government in Tennessee. Master's Thesis, University of Tennessee. http:// trace.tennessee.edu/utk_gradthes/2683.

Buchanan, J. M. (1948). Fiscal Equity in a Federal State. University of Chicago, Ph.D.

Buchanan, J. M. (1949a). The Pure Theory of Government Finance: A Suggested Framework. Mimeo, BP.

Buchanan, J. M. (1949b). The Pure Theory of Government Finance: A Suggested Approach. Journal of Political Economy, 57(6), 496-505.

Buchanan, J. M. (1951). Knut Wicksell on Marginal Cost Pricing. Southern Economic Journal, 18(2), 173-178.

Buchanan, J. M. (1952). The Pricing of Highway Services. National Tax Journal, 5, 97-106.

Buchanan, J. M. (1954a). Resource Allocation and the Highway System. Mimeo, BP.

Buchanan, J. M. (1954b). Consumption Interdependence and the Interpretation of Social Cost. Mimeo, BP.

Buchanan, J. M. (1955a). Painless Pavements: Highways by High Finance. Mimeo, BP.

Buchanan, J. M. (1955b). A Note of the Pure Theory of Public Expenditure. Mimeo, BP.

Buchanan, J. M. (1956). Private Ownership and Common Usage: The Road Case Re-examined. Southern Economic Journal, 22(3), 305-316.

Buchanan, J. M. (1958). Public Principles of Public Debt: A Defense and Restatement. Homewood, Ill.: Irwin.

Buchanan, J. M. (1961). Simple Majority Voting, Game Theory and Resource Use. Canadian Journal of Economics and Political Science, 27(3), 337-348.

Buchanan, J. M. (1962). Politics, Policy and the Pigovian Margins. Economica, 29(113), 17-28.

Buchanan, J. M. (1964). The Highway Network Considered as a Club. Mimeo, BP.

Buchanan, J. M. (1965a). An Economic Theory of Clubs. Economica, 32(125), $1-14$.

Buchanan, J. M. (1965b). Ethical Rules, Expected Values, and Large Numbers. Ethics, 76(1), 1-13. 
Buchanan, J. M. (2007). Economics from the Outside in: "Better Than Plowing" and Beyond. College Station, TX: Texas A\&M University Press.

Buchanan, J. M., \& Kafoglis, M. Z. (1963). A Note on Public Goods Supply. American Economic Review, 53(3), 403-414.

Buchanan, J. M., \& Tullock, G. (1962). The Calculus of Consent: Logical Foundations of Constitutional Democracy. Ann Arbor: University of Michigan Press.

Brownlee, O. H. (1961). User Prices Versus Taxes. In J. M. Buchanan (Ed.), Public Finances: Needs, Sources, and Utilization (pp. 421-432). National Bureau of Economic Research. Princeton: Princeton University Press.

Brownlee, O. H., \& Heller, W. W. (1956). Highway Development and Financing. American Economic Review, 46(2), 232-250.

Coase, R. H. (1946). The Marginal Cost Controversy. Economica, 13(51), 169-182.

Davis, O. A., \& Whinston, A. (1962). Externalities, Welfare, and the Theory of Games. Journal of Political Economy, 70(3), 241-262.

Desmarais-Tremblay, M. (2016). La théorisation des dépenses publiques de Richard A. Musgrave: essai d'histoire de la pensée et d'épistémologie économiques. Economies et nances. Université Paris 1 Panthéon-Sorbonne; Université de Lausanne. https://hal.archives-ouvertes.fr/tel-01475790.

De Viti de Marco, A. (1923). First Principles Of Public Finance. London: Jonathan Cape.

Einaudi, L. (1929). Contributo all ricerca della 'ottima imposta'. Milano: Università Bocconi Editrice.

Hotelling, H. (1938). The General Welfare in Relation to Problems of Taxation and of Railway and Utility Rates. Econometrica, 6(3), 242-269.

Johnson, M. (2015). Public Goods, Market Failure, and Voluntary Exchange. History of Political Economy, 47(Annual Supplement 1), 174-198.

Lerner, A. P. (1944). The Economics of Control. New York: Macmillan.

Marciano, A. (2016). Buchanan's Non-Coercive Economics for Self-Interested Individuals: Ethics, Small Groups and the Social Contract. Journal of the History of Economic Thought, 38(1), 1-20.

Marciano, A. (2018). Buchanan and Public Finance: The Tennessee Years. Review of Austrian Economics. https://doi.org/10.1007/s11138-018-0419-2.

Margolis, J. (1957). Welfare Criteria, Pricing and Decentralization of a Public Service. Quarterly Journal of Economics, 71(3), 448-463.

Martin, J. W. (1923). The Gasoline Tax. The Bulletin of the National Tax Association, 9(3), 73-87. 
Mosca, M. (2016). Antonio de Viti de Marco A Story Worth Remembering. New York: Palgrave Macmillan.

Musgrave, R. A. (1939). The Voluntary Exchange Theory of Public Economy. Quarterly Journal of Economics, 53(2), 213-237.

Pierce, D. (2010). Good Roads Movement, The Tennessee Encyclopedia of History and Culture. http://tennesseeencyclopedia.net/entry.php?rec=554.

Preston, H. L. (1991). Dirt Roads to Dixie: Accessibility and Modernization in the South, 1885-1935. Knoxville: University of Tennessee Press.

Samuelson, P. A. (1954). The Pure Theory of Public Expenditure. Review of Economics and Statistics, 36(4), 387-389.

Simons, H. C. (1937, October). Review of the First Principles of Public Finance, by Antonio de Viti de Marco. American Economic Review, 45, 712-717.

Tiebout, C. M. (1956). A Pure Theory of Local Expenditures. Journal of Political Economy, 64(5), 416-424.

Tullock, G. (1959). Problems of Majority Voting. Journal of Political Economy, 67(6), 571-579.

Wagner, R. E. (2017). James M. Buchanan and Liberal Political Economy. Lanham and London: Lexington Books.

Weingroff, R. F. (2017). Creation of a Landmark: The Federal Aid Road Act of 1916. https://www.fhwa.dot.gov/highwayhistory/landmark.pdf.

Wiseman, J. (1957). The Theory of Public Utility Price-An Empty Box. Oxford Economic Papers, 9(1), 56-74. 